\title{
Reviewing the Critical Conversation about Django Unchained
}

\author{
- Daniel Brount, Mercadies Brown, and Alex Selvey, Ball State University
}

$M$ uch of the critique surrounding the recent film Django Unchained (2012) has been divisive, to say the least. In this essay, we review the critical conversation about this film and explore the parameters of these discussions. By reviewing these critical dialogues about the film, we can examine whether Django Unchained successfully and accurately depicted antebellum slavery in the United States, or if the director, Quentin Tarantino, even intended for the film to do this. By reviewing this critical discussion, we provide the reader with an understanding of Django Unchained and its social, political, and artistic contexts.

\section{Abstract:}

Django Unchained takes place in the Antebellum South and follows a freed slave on his vengeful journey to free his wife. This essay reviews the critical discussion surrounding Django Unchained in order to examine the film's validity both historically and artistically.

\section{KEY WORDS:}

Django Unchained, slavery, film, criticism, Quentin Tarantino, representation, historical acccuracy, Antebellum South

Depicting the system of slavery in America is a difficult venture. Doing so requires filmmakers to balance addressing the violence, brutality, and oppression surrounding slavery, but also keeping in mind the sensitivities of the audience. When Django Unchained premiered in 2012, it was clear that this film was not like slavery films of the past. The film, set in the late $1850 \mathrm{~s}$ in the Southern U.S., shows a slave who is rescued and trained by a bounty hunter to work for his and his wife's freedom. Django Unchained has the characteristics of a traditional Tarantino film, and it explores the spaghetti western style with elements of drama and comedy during the protagonist's journey. As is typical of a Tarantino production, the movie was met with controversy: critics and audiences lined up on two sides of the film, with some deriding what they considered a flippant depiction of slavery and with others praising a bold portrayal of a violent system.

Django Unchained follows Django, a slave, after he meets Dr. King Schultz, a German bounty hunter who needs Django's help identifying the wanted men Shultz is after. The duo strike a deal in which Django will aid Schultz in his search, and in which Schultz promises to liberate Django from his slavery after the bounty has been collected. Shultz begins training Django to be a bounty hunter, and this begins the pair's journey. Django tells Shultz that he wants freedom for his wife Broomhilda as well, from whom he was separated after they attempted to run away. This leads the partners on a journey that ends when they find her at Calvin Candie's plantation.

Critics have focused considerably on the fact that Tarantino is white. Numerous critics have claimed that the film would have been more accurate had a black director created it. In addition, 
people like prominent filmmaker Spike Lee have repeatedly criticized the film for its portrayal of slavery, calling it irresponsible and disrespectful (Zakarin). However, in Django Unchained, most of the black characters are portrayed more positively than the white characters. By the end of the movie, almost every central white character dies, leaving the black characters to tell the end of the story. In their article, "Broomhilda Unchained: Tarantino's Wagner," Adrian Daub and Elisabeth Bronfen point out this twist in traditional storytelling. It is made clear primarily through their perspective on Schultz's death toward the end of the film: "King Schultz almost seems aware that he repeats a gesture familiar from classic Hollywood, in which all non-white characters conveniently disappear in order to let white folks tend to their narrative business at the end of the story. He does not make his decision for ethical reasons; it is narrative that forces his hand" (Daub and Bronfen). By flipping this traditional Hollywood structure on its head, the film avoids reserving negative portrayals for black characters. Instead, it gives the black characters the platform to complete their story.

Django Unchained also makes bold choices in its portrayal of race. In many ways, the film critiques white characters with the portrayal of slave owners as incredibly stupid and/or relentlessly cruel. Many white characters act unintelligently in the film, and others are simply blinded by their racism. Furthermore, Tarantino includes instances such as the comedic proto-Ku Klux Klan scene. A mob of white characters plot to kill Django and Schultz, and these are gestures resembling those of the Ku Klux Klan. The scene focuses on how their attempt comedically falls apart. This is one of the main instances of comedy in the film, for the Klan members spend most of the time arguing about their masks and how the eyeholes were not cut well enough for them to see. Some have argued that this comedic portrayal comes at a cost, making slave owners look like a punch line and ignoring the violence of their actions. In Ebony's article, "The Price of Django," writer Blair Kelley says, "The men and women who owned slaves were not bizarre cartoon villains or the bumbling proto-Klansmen depicted in Django Unchained. They were educated. They attended churches. And, they used their education and religion to try to justify the horror that the majority of their wealth was not in land or livestock, but their ownership of other human beings." According to Kelley, this portrayal of some of these white characters diminishes their cruel role into nearly insignificant comedic caricatures. The film devalues their intelligence and manipulation, instead portraying stupidity as the cause of their cruelty.

The film not only tests the waters of racial tension with its depiction of white characters, but also with its characterization of black slaves. The film portrays their characters in significantly various ways, and the different races are portrayed on many different levels. Black characters range from slaves that work the field, to prominent house slaves, to folk heroes. For example, Samuel L. Jackson's character is a slave who holds dominion over other slaves, often violently. The film addresses slave-on-slave violence, not only through Mandingo fighting, but also by the inclusion of discussions surrounding black slavers. One cannot talk about a film like Django Unchained and not talk about race, but it is worth noting that the depictions of race vary widely.

In analyzing Django Unchained, it is important to look for connections to other film genres, as well as to other Tarantino films. Django's namesake is from the 1966 spaghetti western, Django. Tarantino borrows more than just a name from the genre, placing the main characters in a typical spaghetti western world that "is a place of chaos, devastation, racism, and destructive self-interest" (Ebiri). Django Unchained also matches Tarantino's typical themes of revenge and redemption, such as in Pulp Fiction (1994) and Kill Bill (2003), along with the need for violence to act out that revenge. Django Unchained also mirrors the excessive use of the n-word in films like Pulp Fiction, and debates stand on either side as to whether or not the usage was appropriate. 
Django Unchained also has elements of Blaxploitation films, such the 1975 film Mandingo. As the name implies, the film explores the concept of Mandingo fighting also present in Django Unchained. The 1975 film influenced the creation of Django Unchained, with both containing frequent scenes of brutal violence, especially with the focus on Mandingo fighting. While most scholars believe that Mandingo fighting did not historically exist in American slavery, it has a place in critical discussion of slave films due to its appearance in these two widely debated films (Harris).

Mandingo fighting was not the only element of Django Unchained that is unconfirmed historically. While some claim it was "profoundly ahistorical," the film was not meant to be a historical document (Kelley). It explores fictional characters in familiar situations and does not claim to be completely accurate. Some uses of comedy, such as in the Ku Klux Klan episode, emphasize this point. These instances of comedy give the film a clearly entertainment-based purpose. The film takes place in a historical setting, but that does not mean it has to adhere to historical accuracy in every way.

Since its release in 2012, Django Unchained has been rated and reviewed by numerous critics. In his generally scathing review of the film, Harvey Blume, author of “'Django Unchained” - History Dumbed Down," writes, "History seems to dumb Tarantino down, dull his imagination. The revenge, unfortunately, is on history, which in the process gets painfully dumbed down." Like Blume, Blair L.M. Kelley suggests that the historical inaccuracies make the film painful. Opposing Tarantino's portrayal of slavery in “The Price of Django," Kelley argues that:

In his review, historian Jelani Cobb wondered if the [n-word] was used more frequently in the film than the words 'he' and 'she.' Ironically in the effort to defend the language, Tarantino has clung tightly to claims of historically accuracy. [Tarantino] asserted, 'I don't think anybody is... saying that we used the word more excessively than it was used in 1858 in Mississippi. And if that's not the case then they can shut up'... I wished that Tarantino sought the same kind of accuracy in his larger depictions of the institution of chattel slavery.

Kelley goes on to mention that slave owners often used their education and religion as a way to justify slave-owning, and he wishes that topics like these would have been as heavily addressed as others in Tarantino's film.

Though some suggest that Tarantino's film does lack in accuracy, other critics defend the film, which never claimed to be historically accurate. In her article, "Why Tarantino is Better than Spielberg at Portraying Slavery," Ann Hornaday gives credit to Django for being able to "demonstrate how a history once grievously distorted by cinematic language can be improbably well-served by its most florid, outlandish vernacular." Those siding with Hornaday agree that the lack of accuracy was a small sacrifice to pay to reach the dialogue that was started by Tarantino's decision to portray slavery in such a harsh and violent light.

Whether critics support Tarantino's style or not, the film did get people talking. In Glenda Carpio's piece, "'I Like the Way You Die, Boy': Fantasy's Role in Django Unchained," the author explains that Django is not meant to be understood as a historically accurate work. Carpio points out that Tarantino is "more concerned about movies than anything else" and that his works of fantasy should not be expected to go hand-in-hand with historical accuracy - after all, Hitler was killed by Nazi hunters in Tarantino's portrayal of World War II. Without prior knowledge of Tarantino's other films, viewers could be shocked by the director's portrayal of slavery, but those familiar with Tarantino's stylistic approach could better understand the cinematic value that Django holds.

When it comes to addressing the overdramatic scenes of violence and gore in Django, the audience must remember that this is a style skillfully practiced by Tarantino, and it must be examined 
with that in mind. Like those who dote on the historical inaccuracy of this film, others point out the unrealistic portrayals of slavery, and the overall unnecessary gore and violence that Tarantino flaunts throughout the film. David Denby, the author of "Django Unchained: Put-On, Revenge, and the Aesthetics of Trash," feels that Tarantino's film was nothing more than a "big put-on" and claims that an audience should expect nothing else from this director. Denby ends his relentlessly harsh article by saying, "Django Unchained isn't a guilty pleasure; it's a squalid pleasure." Though some consider Django to be nothing more than a violent, poorly-made gore-fest, there are critics on the other side of the spectrum. Candace Allen finds humor in Tarantino's references to spaghetti-westerns and calls the whole film "an entertaining hoot." Allen's article, "Django Unchained: Is Its Portrayal of Slavery Too Flippant?" boasts her belief that Jamie Foxx's character portrays a film hero for the ages.

Much conversation also surrounds the arguments about the film's connection to Blaxploitation films and spaghetti-westerns. People have often disagreed on what genre Django more accurately represents. Focusing on this argument, DeWayne Wickham claims that the film is more of a Blaxploitation film than a spaghetti-western. In his article, "Django Unchained" really about Blaxploitation," Wickham addresses why Django should be seen as a portrayal of Blaxploitation: "The lack of opportunities for black directors to produce films concerning slavery only increases the controversy surrounding Django ... It is this dearth for opportunities for black directors to do such a major project, as much as Tarantino's treatment of the slavery subject, that fans the flames of the debate over Django Unchained." While those like Wickham agree that Django deals with subject matter unfit to be tackled by a white director, Chris Vognar praises the work. Vognar, author of "He Can't Say that, Can He?: Black, White, and Shades of Gray in the Films of Tarantino," writes: "Tarantino has taken more liberties with racial epithets and black idioms, and written more complicated and fully developed black characters, than any white filmmaker before or since" (24). Vognar concludes his piece stating that Tarantino is being an artist, provoking the audience, and making us ask ourselves tough questions about issues that often get sidelined. Similar to Vognar, Glenda Carpio points out that "pop culture" works like those of Tarantino are able to more easily access sensitive topics than other cultural forms.

Django Unchained was wrought with criticism and controversy since it first was announced. Some labeled $D j a n g o$ as a glorified story of wish-fulfillment and revenge with clear distinctions between good and evil. However, these descriptions used to criticize Django are ones that are the hallmark of stories of heroes. Django Unchained is not, nor does it pretend to be, historically accurate. Instead, Django represents a modern-day folk story of a hero that America wishes could have existed. Almost all depictions of American slavery show African-Americans being denigrated and subjugated. These stories are ones that should be told, as they have their place in modern cinema. Django Unchained takes a new approach to this topic and sacrifices historical accuracy for empowerment.

For Django Unchained to be understood, it must be seen as a hero's journey. This classic trope has existed long before the advent of cinema, let alone Django. The film has almost all tropes associated with this motif. The hero begins in the ordinary world - a victim of slavery's oppression. He meets his mentor who trains him (in this case, with a pistol). As stated by Kerry Washington, a star in the film, the villains Django faced in the film are "some really ugly demons. ... We had to be willing to show the ugly stuff so that the hero's journey meant something" (qtd. in Weiner). Tarantino pulled no punches depicting the villains (slave owners) as violent, racist, and cruel. This moved the story and made the rise of Django that more powerful.

Just as the hero's journey is not a story unique to the works of Tarantino, neither are folk leg- 
ends of slaves avenging their plight at the hands of their masters. In his article about how Django Unchained is a continuation of the "bad black man" folk hero, Scott Reynolds Nelson writes:

Such stories go back to immediately after the Civil War and are partly meditations about slavery and slavery's end. In many of these chants and stories, the bad man was insulted, then cursed at, until he finally shot down white men in saloons and back alleys for failing to treat him with respect. The bad man invariably died at the end of the story. ... Immediately after the Civil War, African-American men built these powerful, folkloric characters in a world where slavery had ended but attacks against black men and women had intensified. The stories of quiet, unpredictable, and violent men who were fearless and died at the end could be simultaneously cautionary tales about the dangers of challenging white authority and covert stories about the thrill of resistance.

These symbols of black power manifested themselves in legends and songs, later appearing in Blaxploitation films. These folk heroes were an inspiration to those who had suffered at the hands of the institution of slavery. Instead of proliferating the narrative of the oppressed slave - which is one that is accurate and worthy of telling - Tarantino takes a page from these folk stories that served to inspire those who were victims of slavery.

The love interest of Django is his wife, Broomhilda. As the viewer comes to learn, her name comes from a German folk tale of a hero who rescues the damsel in distress. This is a not-so-subtle way of showing the heroic nature of Django. On his quest to rescue Broomhilda, Django takes the path of altruism, one frequently treaded by the hero. Django wasn't without flaws, turning a blind eye to travesties around him, but only doing so to maintain his disguise and save his wife. True to the nature of the hero, Django inspired those around him. His mentor, Schultz, was a cynical man who, although he claimed to despise slavery, did nothing to end it until his first encounter with Django. However, by the end Schultz "discovered in himself desires that were greater than material reward. Django's burning desire to rescue his wife [Broomhilda] from slavery, at all costs, gave Schultz hope in something greater than himself. This is what unchained Schultz from a survival of the fittest mentality and allowed him to start living by his deeper principles" (Khoshaba). Heroes inspire us to be greater than who we are, and on his quest, Django spurred that change in his mentor.

In most stories of heroes, the hero is measured by their villain. Their contrast displays a hero's true nature. This is no different in Django. Villains in Django are depicted on the evil side of a clearly-defined division of right and wrong. The scene depicting the proto-Klan mob attempts to "counter the racist polemic of D. W. Griffith's Birth of a Nation. Hence the scene of buffoonish Ku Klux Klansmen complaining their hoods don't fit right; they can't see through the eyeholes. [... ] Tarantino wants to mock its portrayal in the hugely influential D. W. Griffith movie, which treated Klansmen as heroic, the only force between the South and black savagery" (Blume). Instead of applauding their machismo and bravado, they are instead depicted as stupid and ignorant. Additionally, the main villain in the film, Calvin Candie, is a vicious slave owner who pits slaves against one another to fight for his amusement. Not only is he depicted as cruel, but there is a strong implication of an incestuous nature in his relationship to his sister. Once again, the villains are painted as a stark contrast to Django's altruistic nature.

The elements listed previously are commonplace in the movies of heroes, but are new to films depicting slavery. In telling the story of the hero, not only is Django unchained, but so is the display of violence. The film graphically depicts scenes of whipping, slaves being eaten by dogs, slaves fighting to the death, and explosive gunshot wounds. Some have claimed that these depictions of violence cheapen the reality of slavery and that Tarantino is capitalizing on the harsh lives 
of slaves to make an action movie. Others have claimed that the use of comedy in the story is an insult to slaves and those who have ancestors who were enslaved.

However, the use of comedy, action, and blood all serve a larger purpose. Django Unchained doesn't fit into the existing genres of films depicting slavery. By extension, it reaches audiences that would otherwise not be reached by films such as 12 Years a Slave. According to Bob Cesca, "Tarantino has duped a lot of movie-goers into seeing a film about the monstrous, cancerous true nature of American slavery, and I'd wager that a considerable number of people who saw Django Unchained probably didn't see Spielberg's Amistad or The Color Purple or any other historical drama about slavery, many of which were sanitized for mass appeal." Instead of sanitizing the movie to reach a larger audience, Tarantino took the risk on making a film that pushes the envelope and reaches audiences that wouldn't typically find themselves in a theater for a movie about slavery.

The graphic nature of the film is one that attracts some of the most criticism. However, this violence serves a larger purpose: to display the horrific past that America tends to ignore or water-down. As Cesca said,

Even if Tarantino exaggerated the horror of slavery and even if it were only half as awful as he portrayed it, shame on the United States and shame on the framers for not eradicating it from the very start when they had the chance. Maintaining the institution only pandered to a mentally ill demographic of lazy, cheap, sadistic white aristocrats [who] were mentally deranged serial killers hiding under the threat of secession. And they were allowed to get away with it because no one dared undermine the southern economy.

Tarantino shone a light on a part of American history that isn't talked about. The film is bloody, violent, and cruel, but so was slavery. African Americans were violently dehumanized and exploited for generations, and a movie that brazenly depicts violence is necessary in telling that story.

For all the criticism facing Django, no one can say that it didn't start a dialogue. By reaching audiences that don't typically watch slavery movies and by depicting the violence in such a graphic nature, it has spurred discussion amongst critics, academics, and viewers alike. In an interview, Tarantino explained how he wanted to depart from the cut-and-dry slavery movies he had seen in order to make a film that grabbed the audience's attention:

There hasn't been that many slave narratives in the last, you know, 40 years of cinema. ... And for the most part, most of these TV movies or specials that come out are kind of what I call - they're historical movies; like, history with a capital H. Basically, this happened, then this happened, then that happened, then this happened. And that can be fine, well enough, but for the most part I think they keep you at arm's length dramatically because also there is this kind of level of good taste that they're trying to deal with about the history of the subject. And frankly oftentimes they just feel like dusty textbooks just barely dramatized. ... I wanted to tell the story as a genre movie, as an exciting adventure." (Tarantino)

Many critics see the value in this approach, as we can see in Hornaday's argument that, in order to "capture the perversity of a system of kidnapped human beings who were routinely bought, sold, raped, maimed and murdered, it takes genre filmmaking at its most graphic and hyperbolic. How else can movies make proper symbolic sense of America's bloodiest, most shameful chapter?" Django Unchained may not be a shining example of tastefulness in cinema, but it departs from this for good reason. By showing imagery that is violent and grotesque, it works to accurately depict a time in American history that was also violent and grotesque. 
Django Unchained is certainly one of the most bold, distinct movies about American slavery that has ever been produced. A lot of the points raised against Django Unchained have some validity to them, but it is important to remember this movie was made with entirely different aims than most movies depicting slavery. The choices that Tarantino made in regards to this film were not ones any other filmmaker would have likely ever made. He didn't make historical accuracy and political correctness the primary focus on the film. Claiming that it should defeats the true purposes of the movie, to tell a story and to start a dialogue. By making a slave movie so different than the ones before it, Tarantino crafted a film that hits audiences differently, opens new avenues of discussion, brazenly depicts the violence of American slavery, and allows for moviegoers to see a film about an empowered slave character that retakes what is rightfully his. Not every film about slavery should be like Django Unchained, and there certainly will never be another film quite like it. 


\section{WORKS Cited}

Allen, Candace. “Django Unchained: Is Its Portrayal of Slavery Too Flippant?” The Guardian. 10 Jan. 2013. Web. 16 Sept. 2014.

Blume, Harvey. "Short Fuse: "Django Unchained" - History Dumbed Down." The Arts Fuse. 1 Jan. 2013. Web. 14 Sept. 2014

Carpio, Glenda R. “'I Like the Way You Die, Boy': Fantasy's Role in Django Unchained.” Transition 112 (2013): iv-12. Web. 16 Sep. 2014.

Cesca, Bob. "Why Django Unchained Is One of the Most Important Movies of the Year." Huff Post Entertainment. 11 Jan. 2013. Web. 15 Sept. 2014.

Daub, Adrian, and Elisabeth Bronfen. “Broomhilda Unchained: Tarantino’s Wagner.” Jump Cut: A Review of Contemporary Media. Fall 2013. Web. 15 Sept. 2014.

Denby, David. “'Django Unchained': Put-On, Revenge, and the Aesthetics of Trash.” The New Yorker. 22 Jan. 2013. Web. 16 Sept. 2014.

Ebiri, Bilge. “Why Django Unchained's Slavery Tale Had to Be a Spaghetti Western.” Vulture. 2 Jan. 2013. Web. 7 Dec. 2014.

Harris, Aisha. "Was There Really 'Mandingo Fighting' Like in Django Unchained?” Slate.com. Dec. 24, 2012. Web. March 1, 2015.

Hornaday, Ann. "Why Tarantino Is Better than Spielberg at Portraying Slavery." The Washington Post. 14 Feb. 2013. Web. 15 Sept. 2014

Kelley, Blair L.M. “The Price of 'Django.” Ebony. 14 Jan. 2013. Web. 15 Sept. 2014.

Khoshaba, Deborah. “Django Unchained: A Film Analysis.” Psychology Today. 18 Jan. 2013. Web. 15 Sept. 2014.

Nelson, Scott Reynolds. “'Django' Untangled: The Legend of the Bad Black Man.” The Chronicle of Higher Education. 11 Jan. 2013. Web. 15 Sept. 2014.

Tarantino, Quentin. Interview by Terry Gross. "Quentin Tarantino, 'Unchained' And Unruly.” Fresh Air. National Public Radio. 02 Jan 2013. Radio. 16 Jan 2015

Vognar, Chris. ''He Can't Say That, Can He?': Black, White, and Shades of Gray in the Films of Tarantino." Transition 112 (2013): 23-31. Web. 16 Sep. 2014.

Weiner, David. “'Django’ Ugliness Required for Hero's Journey.” ET Online. 18 Dec. 2012. Web. 15 Sept. 2014

Wickham, DeWayne. "Django Unchained Really About Blaxploitation.” USA Today [serial online]. n.d.: Available from: MasterFILE Premier, Ipswich, MA. Web. 16 Sep. 2014.

Zakarin, Jordan. “Spike Lee: 'Django Unchained' Is 'Disrespectful,' I Will Not See It.” The Hollywood Reporter. 24 Dec. 2012. Web. 23 Mar. 2015. 